\title{
tilda
}

Staidéar Fadaimseartha na hÉireann um Dhul in Aois

The Irish Longitudinal Study on Ageing

\section{In Their Own Words: The Voices of Older Irish People in the COVID-19 Pandemic}

Niall Costello, Mark Ward, Paul O'Mahoney, Rose Anne Kenny

\begin{tabular}{|c|c|c|c|c|c|c|}
\hline $\begin{array}{r}\text { "With the } \\
\text { lockdown, life as }\end{array}$ & $\begin{array}{l}\text { "To be able to } \\
\text { travel around }\end{array}$ & $\begin{array}{l}\text { "Going for a meal, } \\
\text { theatre, concert. }\end{array}$ & $\begin{array}{l}\text { "[l look forward to] } \\
\text { a creamy pint of }\end{array}$ & $\begin{array}{l}\text { "The worst part } \\
\text { was not being able }\end{array}$ & $\begin{array}{r}\text { "It was very } \\
\text { frightening as I did }\end{array}$ & $\begin{array}{r}\text { "To see family \& } \\
\text { friends, my }\end{array}$ \\
\hline $\begin{array}{l}\text { we knew it } \\
\text { suddenly stopped!" }\end{array}$ & $\begin{array}{l}\text { reland at my own } \\
\text { leisure." }\end{array}$ & $\begin{array}{r}\text { Hope my choir will } \\
\text { get up and running } \\
\text { soon." }\end{array}$ & Guinness" & $\begin{array}{r}\text { to see my mother } \\
\text { for nearly } 4 \\
\text { months." }\end{array}$ & $\begin{array}{r}\text { not want my .... } \\
\text { grandchildren or } \\
\text { myself to get } \\
\text { unwell." }\end{array}$ & $\begin{array}{l}\text { grandchildren, and } \\
\text { great grandson." }\end{array}$ \\
\hline
\end{tabular}

\section{tilda.tcd.ie}




\title{
In Their Own Words: The Voices of Older Irish People in the COVID-19 Pandemic
}

\author{
Niall Costello, Mark Ward, Paul O'Mahoney, Rose Anne Kenny
}

The Irish Longitudinal Study on Ageing

On behalf of the TILDA team

July 2021

Copyright $\odot$ The Irish Longitudinal Study on Ageing 2021

The Irish Longitudinal Study on Ageing

Trinity College Dublin

Dublin 2

Tel: +35318962509

Email: tilda@tcd.ie

Website: www.tilda.ie

ISBN: 978-1-907894-37-4

https://www.doi.org/10.38018/TildaRe.2021-04 


\section{Acknowledgements}

The Principal Investigator Professor Rose Anne Kenny, project lead Dr Mark Ward and co-authors would like to thank the Health Research Board for funding this research under the COVID-19 Pandemic Rapid Response Funding Call (Grant no. COV19-2020-070). The authors are grateful also to the funders of TILDA: the Department of Health, the Health Research Board, Atlantic Philanthropies and Irish Life plc. The views expressed in this report are not necessarily those of the funders, and responsibility for any errors or omissions rests with the authors alone.

The authors gratefully acknowledge the input of coapplicants and collaborators in the project: Dr Breda Smyth of the Health Service Executive; Ms Edel Byrne, Ms Aisling McGrath and Ms Mary Lovegrove of Men's Sheds Ireland; Mr Sean Moynihan CEO, of ALONE; Professor Roger O'Sullivan of the Institute of Public Health; Professor David Weir, University of Michigan; Professor Axel Börsch-Supan, Max Planck Institute for Social Law and Social Policy (MPISOC), Munich; Professor Jinkook Lee, University of Southern California; Professor Andrew Steptoe and Dr Daisy Fancourt, University College London; Dr Michelle Kelly-Irving, Université Paul Sabatier Toulouse III; Professor Kieran Walsh, National University of Ireland Galway; and Professor Frank Kee, Queens University Belfast.

Special thanks in this project are due to TILDA's administrative staff and data team for processing of data and preparation of the dataset: Ms Anna Davies, Mr Keith Brennan, Ms Tara Nesbitt, Mr Kevin Organ, Dr Siobhán Scarlett, Ms Minjuan Wang and Mr Sameh Hassan, supported by Ms Sinéad McLoughlin, Ms Maria Gillan, Ms Rajalakshmi Balachandra Rao, Ms Sharwari Apte and Ms Mary O'Shea.

Sincere gratitude is due to our valued TILDA participants. This report would not have been possible without their time and generous effort, and their willingness to share their experiences of the COVID-19 pandemic.

\section{Scientific Advisory Board}

Professor James Smith (Chair), Professor James Banks, Professor Aartjan Beekman, Dr Lisa Berkman, Professor Axel Börsch-Supan, Professor Carol Brayne, Professor Robert Clarke, Dr Elaine Douglas, Professor Oscar Franco, Professor John Henretta, Dr Ann Hever, Professor Rose Anne Kenny, Professor Stacy Tessler Lindau, Professor Finbarr Martin, Dr Bernadette McGuinness, Professor James Nazroo, Professor Anne Newman, Dr Paul O'Mahoney, Professor Carol Ryff, Professor Roman Romero-Ortuno, Professor Andrew Steptoe, Professor Ian Young, Professor David Weir, Professor Robert Wright.

\section{Oversight Board}

Mr Brendan Tuohy (Chair), Ms Niamh Clarke, Ms Mairead Creed, Dr Orna Donoghue, Mr Alan Flynn, Professor Martina Hennessy, Dr Ann Hever, Dr Avril Kennan, Mr Brendan Kenny, Professor Rose Anne Kenny, Mr Brendan McEvoy, Professor Hannah McGee, Mr Maurice O'Connell, Dr Paul O'Mahoney, Professor Roger O'Sullivan, Professor Roman Romero-Ortuno, Dr Breda Smyth, Professor James Wickham.

\section{Steering Committee}

Professor Thilo Kroll (Chair), Ms Celine Brosnan, Ms Niamh Clarke, Dr Hilary Cronin, Professor Roman RomeroOrtuno, Ms Lucy Doogan, Dr Orna Donoghue, Mr Michael Foley, Professor Louise Gallagher, Dr Matthew Herring, Dr Ann Hever, Professor Anne Hickey, Professor Patricia Kearney, Professor Frank Kee, Professor Rose Anne Kenny, Professor Richard Layte, Dr Anne Nolan, Professor Charles Normand, Dr Paul O'Mahoney, Professor Orla Shiels, Dr Emma Wallace, Dr Kieran Walsh.

\section{Executive Committee}

Ms Niamh Clarke, Dr Orna Donoghue, Ms Lucy Doogan, Dr Ann Hever, Professor Rose Anne Kenny, Professor Charles Normand, Ms Sonya Perkins, Dr Paul O'Mahoney, Professor Richard Reilly, Professor Roman RomeroOrtuno, Professor Steve Thomas. 


\section{Contents}

Chapter 1 Introduction 


\section{Key findings}

\section{Chapter 2 Methodology}

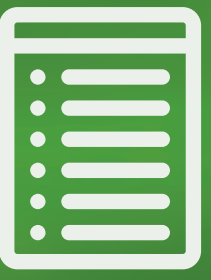

This COVID-19 study was carried out by The Irish Longitudinal Study on Ageing in Ireland.

TILDA participants were recruited from the nationally representative sample of community dwelling adults aged $60+$ in Ireland.

The sample size for this report was 3,964.

Self-Completion Questionnaires (SCQs) were posted to participants home addresses and returned by pre-paid post.

A thematic analytic technique was applied to the open-ended responses provided by TILDA participants, which yielded a number of pertinent themes related to the COVID-19 pandemic.

TILDA is co-funded by the Government of Ireland through the Department of Health, by Atlantic Philanthropies, and by Irish Life PLC. The COVID-19 study described in this report is funded by the Health Research Board under the Rapid Response Research and Innovation Fund.
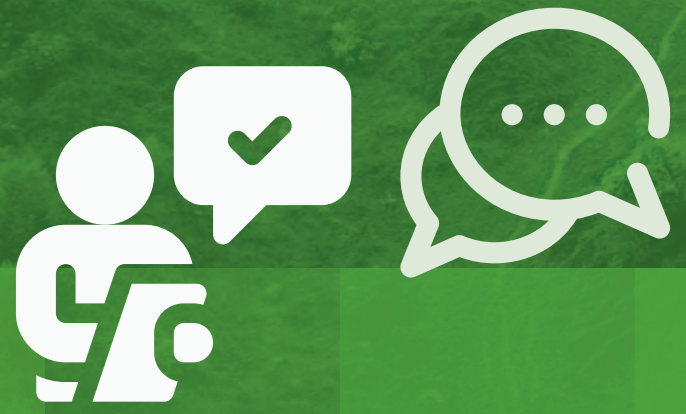

\section{Chapter 3 Normality}

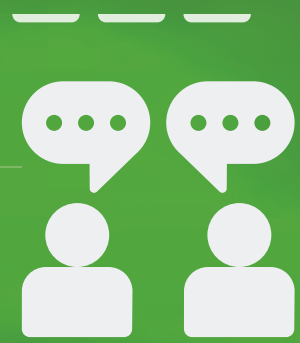

Of the TILDA participants surveyed, $10 \%$ used terms that referred to "normality" when describing the general impact that the pandemic had on their lives.

Many participants voiced their frustration over the disruption to their normal everyday experiences such as missing access to regular community services or meeting family and friends.

Many participants who were still working at the time of the pandemic discussed the challenges of losing their jobs or experiencing an increase in working hours due to their role as essential workers.

Several participants also commented upon the effect that the pandemic had on their normal religious practices such as attending mass and funerals.

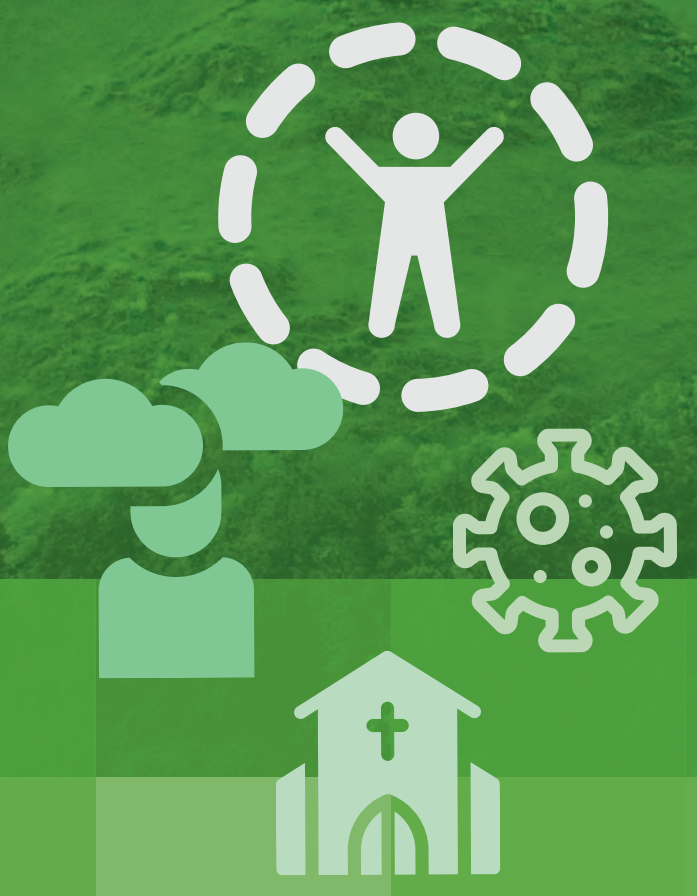




\section{Key findings}

\section{Chapter 4 Resilience}

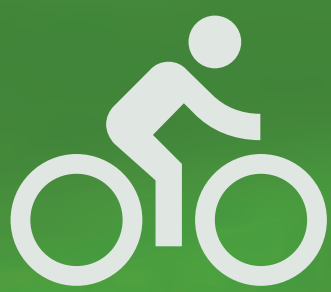

$17 \%$ of respondents used words or phrases that indicated a capacity to cope or demonstrated resilience to the challenges of the pandemic.

Many participants demonstrated a positive outlook and discussed how the pandemic instilled a sense of gratitude for the pleasures and activities remaining in their lives.

Other participants voiced how they coped with the pandemic by adapting swiftly and getting on with their individual duties.

A number of participants discussed how they took the opportunity of restrictions to take up a new skill or hobby such as becoming more computer literate or taking up a new language.

\section{Chapter 5 Social Isolation}

$20 \%$ of respondents used words or phrases that referred to the theme of social isolation or loneliness.

Participants regularly voiced that their greatest challenge was coping with the loneliness associated with the pandemic.

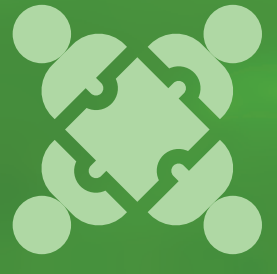

The recommendation that over $70 \mathrm{~s}$ 'cocoon', and the use of the word, was a source of frustration. Many participants found the word disrespectful and difficult to understand in terms of public health advice, and some felt it personally unnecessary.

Some participants commented upon their frustration at feeling neglected and disregarded by the media or public health commentators.

Several participants also voiced their growing anxiety and fear for the future.

\section{Chapter 6 Hope \& Optimism}

Of the respondents surveyed $55 \%$ used words and phrases that referred to hope and optimism for the future when they were asked what they most looked forward to.

Most participants had strong desires and aspirations to meet up with children and grandchildren, as well as broader family and friends.

Many voiced their desire to re-engage with activities that had been suspended due to COVID-19.

A number of participants commented on their hope to see a more just society emerge once the pandemic finally ends.
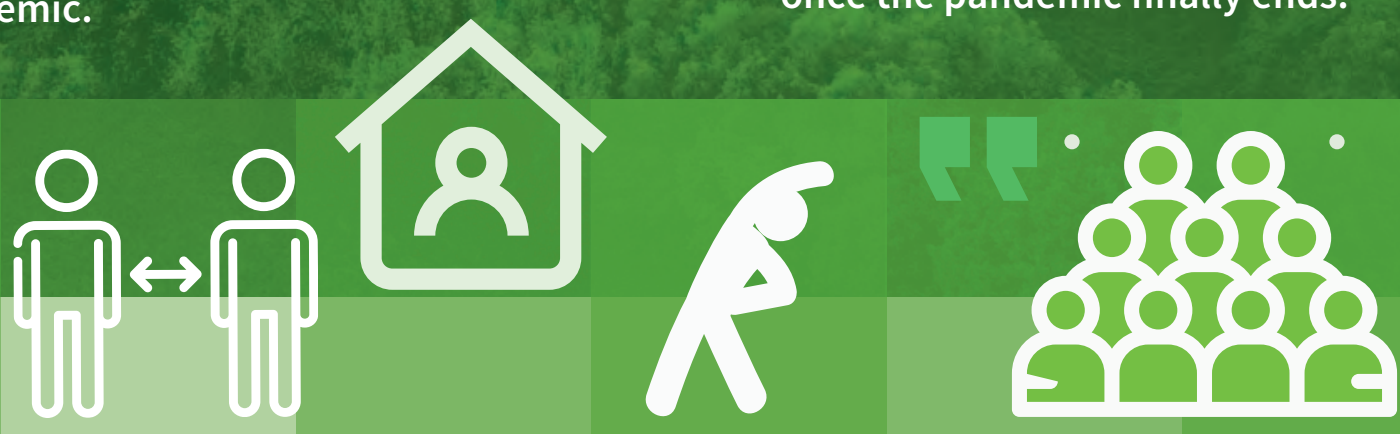


\section{Chapter 1 Introduction}

\subsection{Literature Review}

Since COVID-19 was declared an international pandemic by the World Health Organisation (WHO) in March 2020 (HSE, 2021), older people have carried the greatest burden of serious infection and death from the virus. Internationally, almost $96 \%$ of deaths due to COVID-19 infection occurred among those over the age of 70 (Ioannidis, Axfors, \& Contopoulos-loannidis, 2021). Within the Republic of Ireland to date, $93 \%$ of deaths have occurred in this age group (HSE, 2021). This age group is moreover disproportionally affected by serious infections leading to hospital admissions. In addition to mortality and physical illness, the pandemic's effect on older Irish people's mental health has been documented in a previous COVID-19 study by TILDA researchers (Ward, O'Mahoney, \& Kenny, 2021). This showed that $21 \%$ of participants had clinically meaningful levels of depressive symptoms, while $29 \%$ reported stress levels that were significantly high. The overall life satisfaction was relatively low among TILDA participants, with 37\% reporting low levels of satisfaction with life.

Such statistics cause concern for the health and wellbeing of older people, but much evidence suggests that the experience of and resilience to crises among older people can vary considerably (Chen, 2021). Older people in high-risk groups, particularly those suffering from one or more chronic illnesses, are much more likely to experience challenges regarding their physical and mental health in times of crisis. A variety of factors can mitigate these challenges, however. High levels of intrinsic personal resilience can act as a buffer against illhealth and personal challenges among older people (Windle, Woods, \& Markland, 2010), and levels of personal resilience have been significantly associated with the strength and quality of older peoples' family and social networks (Wells, 2010). Likewise, while the restrictions of the pandemic affected all older people equally, some initial evidence suggests those older adults more familiar with information technologies and social media were better-placed to find alternatives to face-to-face contact and medical engagement (Age NI, 2020). This likely reduced their concern regarding the prospect of a personal crisis occurring during the period of high restrictions.

This variety in the capacity to cope with and adjust to the new normal during a crisis period requires an additional insight into the lived experience among older people. One recent piece of qualitative research conducted by Age Northern Ireland with a small sample of older people showed the variety rather than homogeneity of experiences, with some finding the isolation of lockdown more challenging than others (Age NI, 2020). Few studies to date, however, have explored older people's experience of COVID-19 in this way, i.e. by directly soliciting personal responses. TILDA was ideally placed to do so by reaching out to its nationally representative sample of older people in Ireland and requesting their experience of the pandemic.

This report presents a summary of those experiences, grouped into main themes as reported by TILDA participants in their own words during the first period of lockdown. Presenting these voices not only acknowledges the value of such experiences but may also serve to challenge negative perceptions and stereotypes of older people that were a feature of some narratives in the period covered by this research.

\subsection{Structure of the Report}

The report begins with a description of the TILDA COVID-19 Self-Completion Questionnaire (SCQ) and the methodology used to collect information on the experiences of adults aged 60 years and older during the COVID-19 pandemic. Specific attention will be paid to the qualitative, open-ended questions asked at the end of the COVID-19 SCQ, on which the material in this report is based. Additionally, the analytic approach to data analysis will be described in detail.

In Chapter 3, the theme of normality as discussed by TILDA participants will be described. Four subthemes emerged through analysis of the commentaries, disruptions to participants' public life; private life; working and occupational life; and religious life. Chapter 4 explores participants' commentaries under the theme of resilience. Three subthemes related to resilience clearly emerged: contributions on the topic of gratitude and positivity; how participants adapted to restrictions; and lastly how some participants opened themselves to new opportunities.

Chapter 5 focuses on the challenging aspects of social isolation during lockdown, the subthemes of loneliness; frustration with restrictions; and fear and anxiety related to isolation.

Chapter 6 covers the theme of participants' hope for and optimism about the future. Three principal subthemes that emerged from contributions order this discussion: spending time with family and friends; reengagement with halted activities; and finally, hope for a better society once the pandemic has ended. 


\section{Chapter 2 Methodology}

\subsection{Introduction}

The study protocol (Ward, Clarke, Wang et al, 2021) and research report (Ward, O'Mahoney, \& Kenny, 2021) describe in detail all the methodology and procedures used in the study.

Due to restrictions on household visits and face-to-face interactions in response to the COVID-19 pandemic, it was not possible to conduct in-person interviews for this COVID-19 study. Therefore, Self-CompletionQuestionnaires (SCQs) were mailed to TILDA participants at their home addresses. Once completed, participants then posted the questionnaires back to TILDA using a prepaid envelope provided by TILDA. Data collection began in early July 2020, while the first national lockdown was in place. In September and October 2020, TILDA contacted by telephone all participants who had not yet returned a questionnaire to encourage participation. The final completed questionnaires were received by TILDA in November 2020.

\subsection{Funding}

TILDA is co-funded by the Government of Ireland through the Department of Health, by Atlantic Philanthropies, and by Irish Life PLC. The COVID-19 study described in this report is funded by the Health Research Board under the Rapid Response Research and Innovation Fund (Ref. COV19-2020-070).

\subsection{Ethical Approval}

Ethical approval for the wider TILDA study was granted by the Faculty of Health Sciences Research Ethics Committee in Trinity College Dublin. TILDA adheres to the guidelines set out in the 1964 Helsinki declaration and its later amendments. Ethical approval for this COVID-19 study was obtained from the Irish National Research Ethics Committee COVID-19 on 17th June 2020, reference number: 20-NREC-COV-030-2.

\subsection{Survey Instrument}

Participant information was collected by Self-Completion Questionnaire (SCQ). Regarding the quantitative component of the SCQ, the research was motivated by several key considerations which have been discussed elsewhere (Ward, O'Mahoney, \& Kenny, 2021).

To provide participants with the opportunity to describe their experiences of the pandemic in their own words, and to measure its impact on the older population, two openended questions were included within the SCQ. These questions asked:

1) How you would describe the general impact that the COVID-19 pandemic has had on your life during this period?

2) What is it that you are looking most forward to do once COVID-19 ends?

\subsection{Response Rate}

A total of 5,535 booklets were posted to the study participants aged 60 and older and 3,964 of those responded, achieving a response rate of $71 \%$ during a turnover period of less than five months. In several cases, respondents' spouses who were under the age of 60 were also provided with a SCQ to complete and return to TILDA $(\mathrm{N}=204)$.

\subsection{Qualitative Methodology: Analytic Approach}

This study used thematic analysis to identify patterns or themes in the responses provided to the two open-ended questions included in the SCQ. Thematic analysis is a useful technique for reducing the quantity and complexity of qualitative data into core categories, subjects, or themes, and more importantly it provides a clear framework within which to understand a large body of qualitative data (Bryman, 2012). The method requires coding qualitative content into themes and subthemes relevant to the research question as they emerge, through repeated review of the data (Braun \& Clarke, 2006). In the context of the TILDA report, thematic analysis involved reading and reviewing the open-ended responses provided by TILDA participants. Common experiences or accounts of life under lockdown were coded and grouped under themes, for example normality or isolation; specific subthemes were identified, such as public life under the theme of normality, or fear and anxiety under the theme of isolation. The process required several reviews of the responses to determine which themes were most prevalent and in which order they should be placed for the purposes of discussion. 


\subsection{Participant confidentiality}

Explicit informed consent was obtained from all participants prior to data collection. Protecting the identity of participants is of paramount importance in TILDA. Therefore, in all cases, the responses quoted in this report have been pseudonymised, and each respondent has been further supplied with a pseudonym for the protection of their identity. Likewise, names of institutions, specific locations such as counties or towns, job titles and any other potential identifiers have been removed. Finally, any questionnaires which included extremely sensitive or distressing information were highlighted to senior TILDA staff and contact was made with these participants to confirm they were agreeable to share this information using a pseudonym.

\subsection{Characteristics of participants}

The sample included in the analysis is of TILDA participants aged 60 years and older (including some respondents' spouses under the age of 60 ) who returned a completed COVID-19 SCQ in 2020. As shown in Table 2.1, the average age of participants is 71 years, and $51.4 \%$ are aged 70 years or older. There is a higher percentage of women $(57.1 \%)$ than men $(42.9 \%)$. Over $42 \%$ of participants attended third level education, while $18.7 \%$ left the education system before completing secondary level. Just over one-in-four participants live alone, while the remainder lived with at least one other person, most commonly a spouse. Finally, just over one quarter of those who completed the questionnaire live in Dublin City or County, $28.5 \%$ live in another town or city, and the remaining $44.8 \%$ live in a rural area, as defined by the Central Statistics Office.

\begin{tabular}{|c|c|c|}
\hline Sample & $\begin{array}{r}\mathbf{N} \\
3,964 \\
N\end{array}$ & $\begin{array}{r}\text { Mean Age } \\
70.5(36-98) \\
\%\end{array}$ \\
\hline $\begin{array}{l}\text { Age groups } \\
36-59 \text { (Respondents' Spouses) } \\
60-69 \text { years } \\
\geq 70 \text { years }\end{array}$ & $\begin{array}{r}204 \\
1,745 \\
1,996\end{array}$ & $\begin{array}{l}5.17 \\
44.2 \\
51.4\end{array}$ \\
\hline $\begin{array}{l}\text { Gender } \\
\text { Men } \\
\text { Women }\end{array}$ & $\begin{array}{l}1,688 \\
2,247\end{array}$ & $\begin{array}{l}42.9 \\
57.1\end{array}$ \\
\hline $\begin{array}{l}\text { Education } \\
\text { Primary } \\
\text { Secondary } \\
\text { Third Level }\end{array}$ & $\begin{array}{r}703 \\
1,538 \\
1,628\end{array}$ & $\begin{array}{l}18.2 \\
39.8 \\
42.1\end{array}$ \\
\hline $\begin{array}{l}\text { Household Status } \\
\text { Living alone } \\
\text { Living with others }\end{array}$ & $\begin{array}{l}1,035 \\
2,929\end{array}$ & $\begin{array}{l}26.1 \\
73.9\end{array}$ \\
\hline $\begin{array}{l}\text { Household Location } \\
\text { Dublin City or County } \\
\text { Another Town or City } \\
\text { Rural }\end{array}$ & $\begin{array}{l}1,034 \\
1,102 \\
1,732\end{array}$ & $\begin{array}{l}26.7 \\
28.5 \\
44.8\end{array}$ \\
\hline
\end{tabular}

Table 2.1. Sociodemographic characteristics of TILDA COVID-19 study participants 


\section{Chapter 3 Normality}

\subsection{Introduction}

One of the dominant themes that emerged from participants' responses, was the challenge to the normality of life experienced by participants prepandemic, as well as the hope for a quick return to normal everyday social life. Many participants expressed frustration with the degree of disruption caused by the extensive closing down of the economy and the recommendations strictly to limit social and personal contact. In describing how restrictions on normal social activities affected their lives, participants often reflected on how these activities bring meaning, structure and purpose which were lost with their curtailment.

While normality and disruption to everyday activities was a common theme, a range of personal and more specific frustrations were reported by participants. Some participants expressed regret that they no longer had the social outlets provided them by a local pub, bridge playing community, or even the cattle mart. Others focused on the absence of connection with family, with frequent reference made in responses to missing regular meeting of siblings, children and especially grandchildren. Many also found the disruption to working a rrangements brought on by the pandemic particularly difficult to manage. The restrictions to funerals and to mass and other religious services or ceremonies, like c ommunion, and the inability to attend were also $r$ eferenced as sources of regret or anxiety.

Due to the variety and wide-ranging nature of contributions, they have been divided into four subthemes: disruption to public life, private life, occupational / working life, and religious life.

\subsection{Public life}

On the 24th March 2020, the Irish Government announced that all non-essential businesses and local amenities were to close, and 3 days later, on the 27th March, an additional stay-at-home order was announced. All indoor restaurant and café services, community halls, recreational facilities, and any premises that had until this point provided a social outlet for individuals was shut with immediate effect (DEASP, 2020). While these measures affected all members of Irish society regardless of age, older people were especially vulnerable to the effects of these sudden restrictions. For some older people, these amenities and facilities were the only opportunity to socialise regularly outside their household in any given day or even week.
It is perhaps unsurprising that the most common frustration reported by older adults concerned the disruption to these everyday public and social norms. Unable to engage in their regular social activities, participants felt a sizable and significant proportion of their social world had suddenly vanished:

"With the lockdown, life as we knew it suddenly stopped!”

Deirdre, 74

"[It's tough] not being able to do the normal things in life and missing my small piece of social life and visiting my relations and friends."

Patrick, 65

"I used to play cards on Thursday in a pub. I would go to [named bookmaker] now and again to see if I could pick a good horse. But most of all, my wife and myself would go to céilis and do a lot of set dancing, that is the most we miss."

Robbie, 82

"We miss going out with our friends at weekends, for a social night out for a chat and catch up. Music in hotels."

Linda, 77

"My freedom! I have to think every time I go out about distance from other people. Face covering. Not being able to go where I liked. I felt like a prisoner during lockdown. Not seeing most of my brothers and sisters for 6 months. Not joining my friends in the pub at weekends."

James, 74

"It has changed the whole way of life. You can't go just to walk around the shop if you want to, not necessarily to buy anything, just to walk about. I miss that I can't go visiting my brothers and sisters when I feel like it. It will be a long time before things return to anything that was near normal."

Rachel, 72

"Staying at home was very hard, not seeing grandchildren, no bingo, theatre or pictures. You don't miss these things till someone tells you, you can't go!"

Ciara, 71 
In some cases, participants reported the lack of access to public facilities as taking a toll on their physical health:

"The COVID pandemic has had a detrimental impact on my life, and it is ongoing. I am sure I am not alone amongst my age group. I feel older and my physical fitness levels have declined because of being ordered to sequester at home where I had no means of exercising - home is a first floor, tiny one bedroom flat, without access to a garden."

\section{Bernie, 70}

"I am 81 years of age but yet I exercise about five days a week. I go to the gym for the exercises. I missed that very much because I couldn't even go for a walk."

Ben, 81

"General curtailment of movement and interaction with other people. Restricted in travel... Less physical contact with family, friends. No access to gyms for exercise."

Danny, 68

Some participants were also disappointed with how these restrictions were announced, and frustration with the communication of the new pandemic rules was made clear:

"I feel mixed messages from the government was unhelpful. Treating all over 70's without underlying health problems was not beneficial. I live alone and grateful not to have mental health issues, but I know it's difficult if you do."

Abbie, 79

When asked what it was that they most looked forward to once the pandemic eventually ends, most participants were eager to return to these common forms of social engagement:

"Getting back to normal life or at least new normal. Appreciating all that is good in life and taking nothing for granted."

Diarmuid, 65
"To be able to travel around Ireland at my own leisure."

Tim, 63

"Going for a meal, theatre, concert. Hope my choir will get up and running soon."

Hannah, 65

"My only hope is to see this awful virus end, so we can all see an end to it, and live our lives as always (or even better)."

Gillian, 88

"A creamy pint of Guinness in a pub setting."

Sean, 65

\subsection{Private life}

While most recognised the measures were essential to maintaining public health, participants still found the restrictions to private households challenging. One of the most frustrating aspects was the limited contact and engagement with family members. Older adults frequently reported the effect on their family lives with strong emotions, describing the consequences to their family units as the "biggest issue", noting that the restrictions "severely disturbed" their relationships with family, and reporting that the strain on close relationships was "extremely stressful" and "very sad", particularly in cases where participants had previously taken on caring responsibilities. The following quote is a typical example of such frustration:

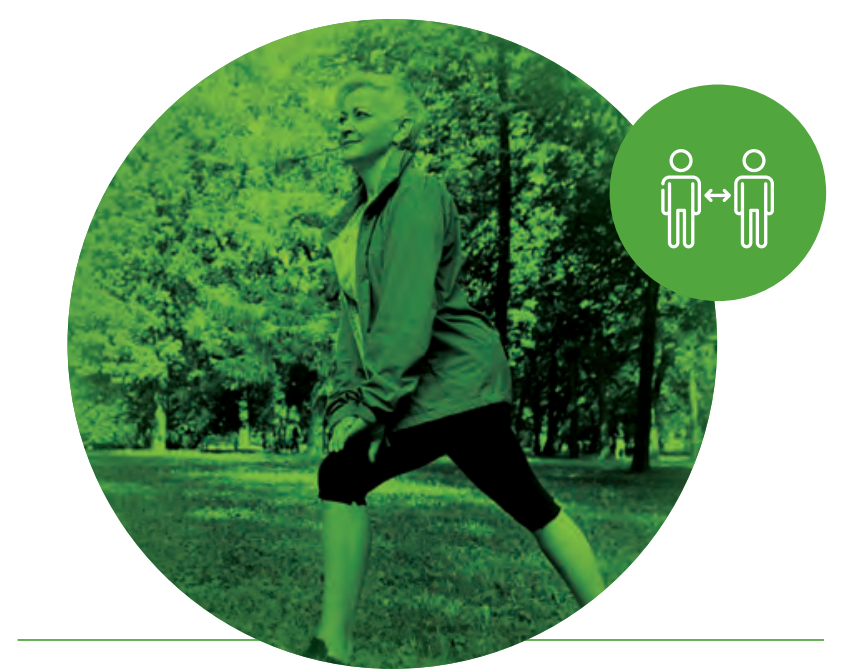


"Was very worried. Going into the unknown, had to stay in for three and half months with my husband not able to see my mum \& dad (both aged over 90). Not able to see \& cuddle my grandchildren. Only able to go out into the garden to get air. I am the helper in the family, help with grandchildren, my mum \& dad, shopping for them. One daughter on her own widowed with children. Very sad I could not do anything to help her. My son \& daughter doing shopping for us. Looking through windows at my grandchildren was the worst thing ever. They did not understand. Only going out once a week, wear gloves and masks, my small grandchildren are a little frightened to come near us."

Emer, 68

The above quote also highlights another common theme related to private life. Specifically, the disruption to relationships and caring arrangements between participants and their parents. This could be particularly distressing, as participants were already of an older cohort and their parents were often quite aged and could be vulnerable to COVID-19 or have enhanced care requirements, or both:

"Made it very stressful as I'm a carer for my parents who are both almost ninety years old. They have been in their house since March only going to Dr. appointments."

\section{Geraldine, 65}

"The worst part was not being able to see my mother for nearly 4 months."

Pauline, 61

"I have missed my father as having been away before COVID, I had to stay away from him."

Josephine, 65

"The pandemic has caused worry for family especially my elderly parents. It is the feeling that there is no end in sight I think is a worry."

Annie, 62
Some participants made the decision to move in with their parents for the duration of lockdown, and discussed the experience and challenges of caring for them:

"I moved in with elderly parents as a result was in effect cocooned with them. Other family members purchased food and essentials and delivered to the door. While it was and is a pleasure to look after my parents, I am looking forward to returning to my own home and try to resume as normal a life as possible."

Helena, 62

One aspect of family life that was clearly difficult for participants was missing contact with grandchildren. Grandchildren featured in the lives of grandparents in many ways, often in a caring capacity, for example school collections, child minding and preparation of meals. Other participants expressed feelings of little or no hope since the pandemic left them with little hope of visits from grandchildren living abroad who might have come with returning parents on summer holidays. Additionally, some participants felt their identity as grandparents had been lost through lack of contact:

"Diminished is the word that best describes how I feel. I went from a part time working, grandchildren minding, school runs, swimming classes, meal-giving grandparent to a locked-in not consulted not engaged adult. My relationship with my younger grandchildren has returned but not the 12 - 14-year olds."

Karen, 68

"Grandchildren got very upset during lockdown and blamed themselves as the reason we could not have close contact."

Frank, 62

"I found it extremely difficult not to be able to see my grandchildren as they have played a major part in my daily life and I looked after the older child."

Louise, 68

"It was very frightening as I did not want my grandchildren or myself to get unwell."

Rebecca, 85 
"I found it very hard to stay home not see my family and especially not seeing my grandchildren."

Mary, 71

"The biggest impact for me is not being able to see my family in particular my grandchildren who live in USA and having to cancel a trip over there in April."

Amy, 66

"I missed my grandchildren so much during lockdown, feel the virus has stolen precious time."

Patricia, 84

When participants were asked what they most looked forward to when COVID-19 restrictions end, spending quality time with their grandchildren was a recurring theme:

"Looking after my two grandchildren. Personally, I lead a very simple life, one day at a time, but always love \& enjoy spending time with my grandchildren, be it going swimming, walking, going to the park, play centres and visiting castles, places of historical interests etc."

Anna, 66

"Make up lost time and to give loads of hugs and kisses to my grandchildren. Miss the close contact."

Catherine, 71

"Travelling to my son and daughter and their respective spouses and my adorable grandchildren"

\section{Ken, 71}

"To see family \& friends, my grandchildren, and great grandson."

Hannah, 80

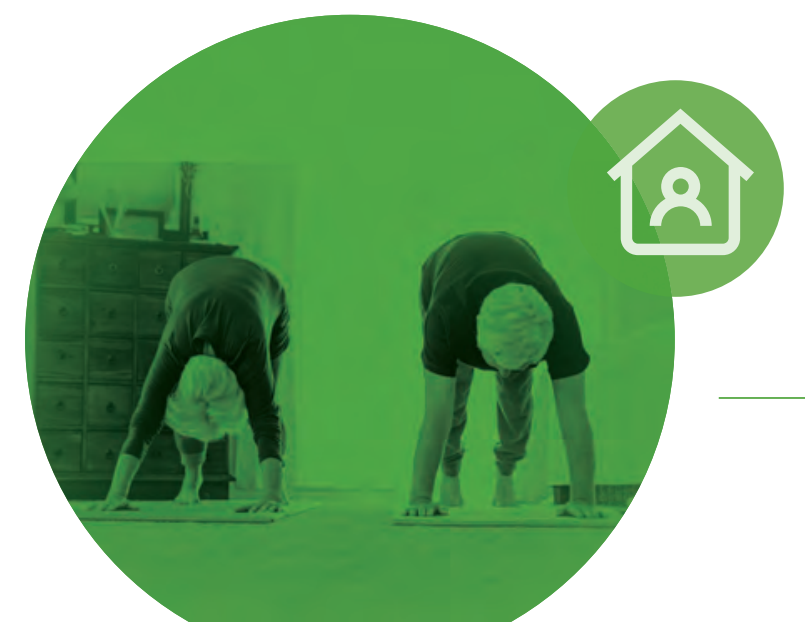

\subsection{Occupational and Work Life}

The pandemic, as well as disrupting family life, also had a dramatic effect on the working lives of older adults, with some participants having their working hours reduced significantly, some being furloughed and some losing their jobs entirely. The loss of working life as part of restrictions was particularly frustrating for many participants, and many expressed real stress and worry about ever returning to employment. In addition to the financial strain of unemployment, participants also referred to the loss of emotional investment and sense of identity that they had developed through their normal working lives.

"It was hard. I am a widow and live alone. I do not have children, so it was all very lonely for me. I was grateful for my job even though we were on 1 day on and 1 day off. I found it hard to get structure on the days I was off. Some days I stayed in bed too long and even though I love walking \& do it a lot, I couldn't motivate myself."

Cynthia, 60

"Firstly, work had to close, it took a while to get used to being at home... Not been able to lead a normal life and when would some form of normality come back to our everyday living."

Beth, 62

"I've been at home since mid-March hoping to return to work soon. While it's been great to spend time with family and my pets, it has also been very stressful. ... ...Days when I didn't see or speak to anyone."

"I was working full time before COVID...Due to the financial impact on our business I am now on a two day week and we will likely close in the next 2 months so I will be out of work. At 62 it will be very difficult to get another job \& I cannot afford this."

Verona, 62

"Loss of job. Unemployed for first time in my working life."

Robert, 62 
One participant who reported having to close their business as a consequence of the pandemic found the emotional impact very difficult to deal with:

"Had to close our business after 40 years. I could not believe how emotional it was. No income was very strange. Not working very difficult mentally at first. Not able to pay our mortgage... That we had broken our lovely world and taken so much for granted."

Martha, 60

In other cases, business owners who had to close temporarily voiced uncertainty about the future of their companies, as well as gratitude for the financial supports provided by the state:

"I am concerned that the closure of my business may in fact be terminal and I am a bit worried about future income. That is for another day. I have enjoyed my down time with my wife and family and if the COVID payment continues I can keep on top of the bills."

Donny, 67

Some changes to employment were due to restrictions on non-essential business, but a number of participants decided to stop working due to their concern of contracting the virus:

"The impact COVID-19 has had on my life is the fact that because of my age, now 71 years old, I had to quit my job. I loved my job, loved the people I worked with, and loved having a life outside of the home and of course I miss not having my 'own' money. I worked in my job for over 20 years. I miss terribly not having the discipline of getting up, dressing up and going to work."

Regina, 71

As well as reduced employment, some participants who worked in essential healthcare settings reported an increase in their working hours or the intensity of their workload. In these cases, participants reported increases in stress and anxiety associated with new work norms and duties.

"I am working in the emergency department of [REDACTED] hospital. I am not on the COVID cleaning team but even so it was a bit scary at times."
"As a care assistant in a residential care home ... I found the hours long due to sleep overs, unsociable hours, cocooning, social distancing hard...had to explain they [residents] would be affected and had to learn to keep their distancing from each other."

Kathleen, 60

"As a carer, I worked 7 days a week about 60 hrs. No respite \& no days off. Hard to deal with Alzheimer's client who didn't understand the confinement. No support for me or her was available. The end result was the lady had to be taken into a nursing home for her own safety. People should be cared for in their homes if that is their wish."

Josepha, 61

Many participants however adjusted to the new work demands and felt both gratitude and a purpose that they could assist at the height of the pandemic:

"I have found a greater involvement in my work was necessary from March due to a surge in demand for healthcare needs and this was initially stressful due to fear of the unknown. Safety measures helped improve confidence of team and camaraderie evolved as our essential role in the community crystallised."

Brian, 60

"I am lucky as I have had my work, otherwise, I feel I would be more alone, depressed to the point where I just wouldn't care about myself. No purpose to get up and go."

Barbara, 62

\subsection{Religious Life}

One aspect of the initial lockdown was how restrictions affected the spiritual practices and religious norms of many older Irish people. These included restrictions on mass and funeral services, as well as disruptions to some participants' personal spiritual experience. This was particularly apparent where participants had experienced bereavement, and this was noted as a particularly challenging aspect of the pandemic: 
"My husband passed away suddenly shortly before lockdown... The combined experience of the lockdown and bereavement is the worst, the saddest, the most emotionally and mentally challenging... As a family I believe our grief was made very complicated by the pandemic, lockdown and isolation."

Caroline, 64

"I was going through a bereavement before COVID and to be honest COVID made things worse for me. Living alone takes a while to get used to."

Andrea, 67

"The sadness of not being able to attend local funerals and fully sympathise with the family over the loss of their loved ones. The difficulty in accepting the fact that the virus has changed our day to day lives and will continue to do so for the foreseeable future."

Bernadette, 80

"Shortly before the pandemic my brother died. We had had a terrible time and are devastated, then COVID-19 came so I had been in a bit of a daze. ... My sibling's passing and the fact that my mother got COVID-19 in her nursing home has had a real impact on my emotions."

\section{Eve, 65}

"The only way I was affected by it was my husband died in March and while we were able to have a funeral for him which we thank god for, the loneliness of being in lockdown really made my grief so much worse."

Heather, 65

"The inability to receive Holy Communion or attend mass was also a source of disappointment for many: "Have not received Holy communion since beginning of March.”

Gerry, 92

"I missed going to mass, not meeting people... We will all appreciate things much better now when COVID is over."

Anne, 63
"I am a daily mass goer and look forward to continuing with this and other religious duties, such as regular confession... Unfortunately, the reception of the Eucharist is not physically possible."

Eddie, 60

Some participants reported a change in perspective as to what may be important in life, as well as an increased sense of their own mortality. Such experiences were accompanied by positive changes to participants' relationships with their spouses and family, as well as encouraging them to live more mindfully:

"It has forced me to think about the really important things in life. It has also made me more conscious of my own mortality. The realisation that life is fragile and finite. I have thought more about family members who have pre-deceased me, my parents, my brother. I have missed the simple things in life for example shopping, going to Sunday mass, getting a haircut. This virus has made me realise that there are factors outside of human control that have a serious effect on our lives."

Padraig, 81

"It was a time like no other I have ever experienced. It started with disbelief that such an outbreak could occur then worry that nearest and dearest would become ill and finally acceptance of a new reality. The actual lockdown was a quiet reflective time and my husband (who is on [REDACTED TREATMENT]) and I enjoyed spending the time together in isolation. It was a time to slow down, read, garden, walk and contact our family in different ways. The silence and lack of traffic and bustle was lovely."

Noreen, 61

"Adopted an attitude 'make do with what you have' rather than heading to shops for clothes, groceries etc...Became more empathetic and sensitive to others affected by COVID-19 and not affected by COVID-19. Increased my volunteering duties and helpline (that was good). Appreciate more my relationship with my husband and the person that he is, more time (enforced) together was good. Gave more time to reflect on what's important and why."

Theresa, 67 


\section{Chapter 4 Resilience}

\subsection{Introduction}

Many older adults adjusted quickly to the new reality faced as the pandemic affected all aspects of their lives. Indeed, in many cases, the changed circumstances of the pandemic were met with good grace and even a positive outlook. Some took the opportunity to reflect on what remained in their lives that they were grateful for; others saw an opportunity to take up a new skill or brush up on an old one, and others still simply adapted and tried to go on with minimum disturbance. This chapter sets out examples of the positive responses and adaptations to the pandemic reported in the survey.

Such reactions to the challenging circumstances of the pandemic demonstrate that many participants display high levels of emotional resilience. These forms of emotional resilience are captured in three themes that emerged: gratitude and positivity; adaptation; and openness to new opportunities. These themes represent ways in which older people in Ireland managed, coped, and adapted despite the most challenging difficulties of COVID-19.

\subsection{Gratitude \& Positivity}

The benefits to personal wellbeing of gratitude and adopting a positive outlook on life have been well documented (Rash, Matsuba, \& Prkachin, 2011) (Killen \& Macaskill, 2015) (Jackowska, Brown, Ronaldson, \& Spetoe, 2016). Fortunately, the presence of positive views and attitudes among participants was well evidenced in the survey. With no prompt to specify or address positive aspects of their experience, TILDA participants regularly reported that the pandemic had caused them to reflect with gratitude on the aspects of their lives that remained unaffected by events. Such practices allowed participants to build a resilient attitude against challenges associated with lockdown, and sometimes helped them to adopt a healthier and more sanguine outlook on their lives:

"It gave us time to reflect to read, to think about all we took for granted. To experience the kindness of other human beings and think of all the people who worked through this time."

Amy, 69

"A very positive impact in that I enjoyed a new pace of life at home, enjoyed my garden \& outside spaces, found a new sense of contentment \& discernment in prioritising my life."

Clodagh, 64
"I became more compassionate, understanding and tolerant of others' reactions and I became grateful daily for what and who I have in my life. I also slowed down - everything."

Noreen, 61

"It has made me even more grateful to live in the country with lots of space and fresh air and lots to do."

$$
\text { Jill, } 64
$$

"It has increased my awareness of being grateful for what I have in terms of health, family, friends, a comfortable home, money enough to live without worry."

Veronica, 67

In some cases, the pandemic had not been the greatest personal challenge to participants' lives, and their sense of gratitude and resilience was already strong:

"COVID-19 hasn't bothered me at all, I had cancer last year \& had half of my right lung removed, I am so happy to be alive!"

Deana, 70

"Unfortunately, I was diagnosed with cancer early this year. I had [REDACTED TREATMENT] and I have been up and down to the hospital for [REDACTED TREATMENT] It has been a trying time, but I keep strong especially for our special daughter whose centre has been closed for the duration of the pandemic. My family and friends have been a great source of help and comfort."

Orla, 73

More general positive experiences also featured in responses. Some involved a change in mood and an appreciation for the slower pace of daily life and space for reflection that the pandemic had brought:

"I have had no problem with COVID-19. In fact, I've begun to enjoy the speed of life, and the less hustle \& bustle of life would be very easy to get used to."

Mikey, 67 
"I really enjoyed lockdown as it gave me the chance to reflect on life and to relax. No stress or pressure to do things or be somewhere."

\section{Fiona, 63}

"Well I lead a very busy life, and in a way, the COVID-19 pandemic was a lovely serene peaceful time in my life, time to enjoy my garden, nature, and close ties with my children."

\section{Bernie, 76}

"I liked the lockdown, the world slowing down and the peace of no traffic. Walking and seeing the beauty around me. Hearing birds sing without the noise of traffic. I found it very peaceful but a bit lonely at times too. I missed my grandkids... but FaceTimed them a lot and got to know them in a deeper way. COVID-19 is bad but maybe it will make us think about what is important in life and what we value. I know I did."

Judith, 65

Other participants looked outwards and gained new appreciation of their personal and family relationships. These became a regular source of positive reflection:

"... Other than that, I feel lucky I live with my husband. We get on so well. It's been lovely."

Laura, 71

"At age 67 living on a farm with my husband and one of my daughters combined with excellent weather I have been in the lucky position of being out and about everyday ... I have not suffered from loneliness or isolation..."

Olive, 67

"I enjoyed the 'down time' with my husband and the lack of necessary routine. I got my energy back. We had wholesome home cooked dinners every day and my husband caught up on garden maintenance which was much needed."

Kathryn, 65
"Covid19 pandemic period was for me a most happy time as I had 3 of my family members back living with me. We had lovely family time and they also helped with household duties and refurbishment of the house. We played board games and shared lovely family meals and would say it was the best thing that happened to me this year."

Bronagh, 69

Some participants were prompted by the pandemic to make the decision to move in with their long-term partners. This allowed them to care for one another while also self-isolating, and to reflect on the support they provided each other:

"My partner and I are both over 70 so when we knew we would have to cocoon, we agreed that he would move in with me for the duration (we normally keep to our own house) so that is if one of us was sick during this time, the other would be able to care for him/her. It also meant we had the constant company of each other which was invaluable, and we were able... to laugh together. It would have been a very different story if I had been alone during cocooning."

Sonya, 70

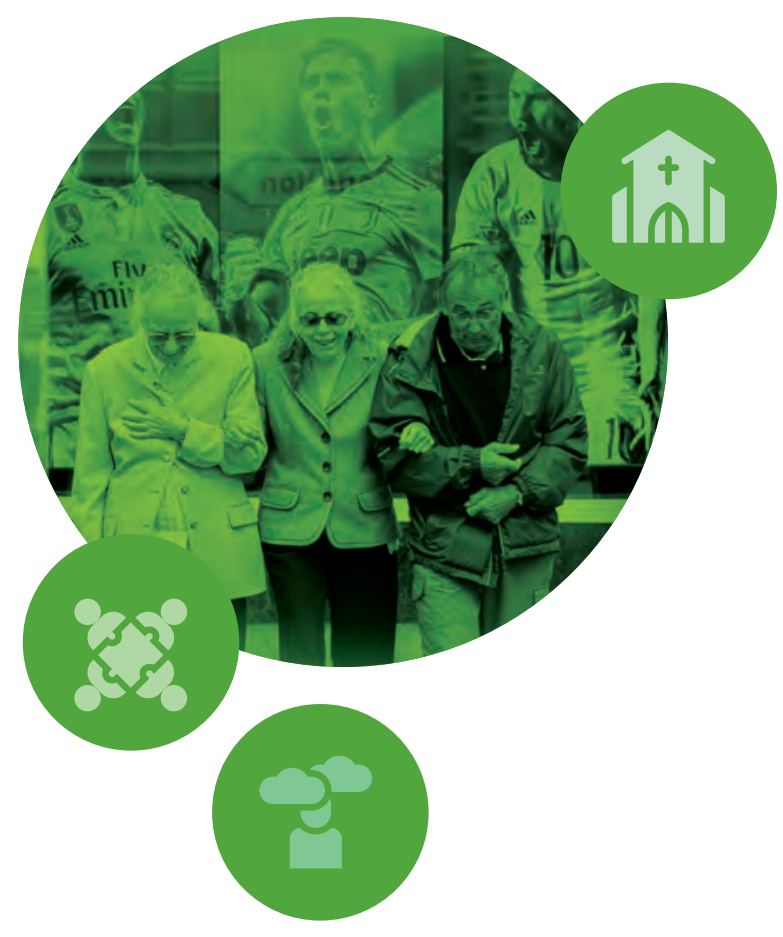




\subsection{Adaptation}

Some participants adapted to the new normal by "just getting on with things", adopting a patient and pragmatic approach to the overall challenge of the pandemic. These participants held on to the regular patterns of their normal life that remained, provided they could do so safely. Some reported that the advice of senior medical experts made it possible to define the limits within which they could maintain their routines:

"In many ways it was just a matter of following the rules carefully and behaving sensibly. The limited amount of external human interaction socially was not nice but thankfully the good weather was a bonus."

Richard, 77

"There was no impact on my life. I worked through COVID-19. I was quite happy working and attending to the outdoor chores about the house."

Lorcan, 60

"Generally speaking, it has not much affected daily living, work has changed slightly, and socially and going out doesn't bother us too much. We are quite adaptable."

\section{Ciaran, 65}

"As time went on and I learned more I got a bit happier and felt able to cope. I am so thankful and grateful to Dr Tony Holohan for getting us all through this time. I trusted him completely."

Nora, 69

A feature of some participants' resilience in the face of the challenges was the adoption or unmasking of a stoical attitude:

"I researched the Spanish flu epidemic in 1918-1920. I now realise how awful it must have been, luckily none of my ancestors seemed to have contracted it. COVID19 has changed my attitude to life. It proves there is not much point in worrying about life. If I get this virus sometime in the future - so be it. I have survived many setbacks in my life. If it should shorten my life, so be it. I will only truly worry if it affects my own children or my grandchildren. I am a stoic and have learned to accept the ups and downs of living with emphasis on living every day as if it's my last."
Other participants made small changes to their daily news and information viewing, which greatly improved mental health and collective wellbeing:

"I feel that months went by and that looking back now, I feel my husband \& I got through it... decided only to watch the news about it only once a day \& definitely not the last thing at night, because sometimes it was all too frightening and you would find it hard to get to sleep."

Izzy, 61

"I watched too much news in the initial stages dementing myself so I made a decision to go with only one news per day (usually RTE 1) - cocooned when told and exercised so much. Feel it slowed us down and appreciated little things so much better - birds singing and beauty of trees."

Harriet, 65

Ability to adapt without too much difficulty was helped by reliance on familiar habits and relationships:

"At my age, I live prudently, have a mature family that is extremely helpful. I planned activities at home to occupy myself during cocooning. The weather was good. I have a loving relationship with my wife of over 50 years."

Tony, 81

"At the beginning of the outbreak, I was a bit unsure, because nobody knew much about the virus, and the pictures from Italy were frightening. I have ... sons in Australia I was concerned about them. So, then I handed all my worries over to the sacred heart as I always do and thankfully everything is grand. My faith is very important to me and I pray for all Irish people that they will put their trust in God, and everything will be okay. I test positive for faith, keep my distance from doubt and isolate myself from fear."

Shelia, 60 


\subsection{Openness to New Opportunities}

A feature of resilience to the challenges posed by the pandemic was participants' taking additional time they found they had to explore new opportunities and areas of interest. People's days were now freer in many respects, and the opportunity was presented to acquire new skills or engage in new activities. Some participants decided to spend their time tending to household chores, whether it be cleaning projects or tending their gardens. Others decided to focus on more leisurely activities like walking and exploring the local area. Additionally, some used the time to take up new skills, from engagement with practical philosophy or sitting computer courses to learning a new language. The desire to use additional time productively and to fulfill potential was common:

"We have had a great quality of daily routine, walking on a long beach, swimming, gardening, landscaping, knitting, cooking, reading etc. We've done courses in French, Italian and have meetings with friends and family online, and yoga and Tai Chi."

Ray, 69

"Quite enjoyed being in a different routine. Did lots of knitting for charity. Read and watched Netflix. Met grandchildren \& family outdoors and enjoyed good weather."

Edna, 79

"I have had a much more 'local' life. I have spent more time on experiencing locally (and safely) and have spent more time working on the house \& garden."

Ronnie, 60

"Initially the inability to go out because of my age bothered me. However, as I got used to it...I enjoyed it. I have a big garden with lots of work to be done. The weather was fabulous and without that I think the lockdown would have been very depressing. I did not miss physical company and satisfied myself on the telephone and Zoom with family and friends. Had weekly sessions/meetings on Zoom for practical philosophy and French language and also played bridge online with 3 friends."

Rebecca, 73
"I am most fortunate where I live as there is a private road behind which I accessed twice daily at noon and 4, walking for a half hour each time 8000 steps got routine and social distancing caught up on reading and got a lot of household tasks and organised a skip and tidied up back garden etc. A lot of my peers enjoyed their 'cocooning' too..."

Carrie, 71

"During cocooning an unexpected positive impact was having time to relax and enjoy my husband's company and my interests and hobbies without feeling that we should be 'doing' something. There was no coming or going, no planning - we could just 'be'. The weather was wonderful so that helped a lot and we live in the country and really appreciate that. I also got better at using my smartphone."

Ursula, 73

"I would say all in all the impact was positive even though I lost most of my work, but the way the government stepped in and helped was just amazing. I also did 2 courses on-line over the 3-month period which was refunded to me through the county enterprise board."

Kevin, 62

Other adults within the study used the time to become more involved with their local community and church groups:

"I continued to do my usual housework. I live with my husband. Cocooning was difficult in the beginning, but I started sewing on my machine and hand embroidery on garments for priests on the missions. That took care of 2 months, then I started making masks from material I had 'good quality cotton'. I sold them to make money for missions as we are unable to raise money because of COVID-19...I wrote more letters."

Francine, 82

"I have used online local church services almost daily and felt included and supported by this. I have enjoyed having time to do craft work, gardening, online computer course and develop computer skills and generally get my affairs in order."

Veronica, 67 


\section{Chapter 5 Social Isolation}

\subsection{Introduction}

For some participants, naturally, the additional time afforded by restrictions did not compensate for what they were deprived of, and the pandemic was a challenging period of serious isolation and increased feelings of loneliness. Participants reported missing family, friends and the caring professionals who had been regular visitors to their lives. Some respondents gave one-word responses such as "Terrifying" or "Shocking" to sum up the effect of the time they had to spend alone. These accounts were more common for older adults who had few or no social supports, or family members in their lives. Additionally, many participants discussed how the events of the pandemic had left them with a growing anxiety about the course that COVID-19 would take in the future. Others were fearful of the future more generally, and the isolation of lockdown only further added to their anxieties. Repeatedly noted as the worst aspect of the isolation was the separation from children and grandchildren, as well as close family and friends. These accounts make clear the importance of human contact and the serious consequences for mental and physical health that even short periods of social isolation can have on individuals. The analysis of participant responses identified commonly reported outcomes of isolation in the pandemic. Of the variety of reported psychological effects of prolonged isolation, the themes which emerged were loneliness, frustration, and fear and anxiety about the future.

\subsection{Loneliness}

The most common effect of social isolation related to the pandemic restrictions was the frequent experience of loneliness reported by participants. Many respondents reported the loneliness of lockdown as the most challenging aspect of the pandemic. While some participants were happy in their own company, many felt lonelier. Additionally, the longer the period of loneliness, the harder the experience, and the more sorrow expressed at being forced to adjust to the restrictions. One participant wrote of how distressing they found the circumstances imposed by restrictions:
"Loneliness was the biggest factor as I did the full lockdown. My sons did my shopping, bill, prescriptions etc. They left the shopping at the door and went to the end of the drive and we talked at a distance. The same when they brought the grandchildren round. Mother's Day and my birthday were terrible, they lit candles on a cake on the wall and sang happy birthday. I cried my eyes out."

Martha, 71

Many participants described how as time passed and feelings of loneliness endured, they felt less connection to the wider community; these participants were more likely to report feelings of fear:

"I am afraid to leave the house in case I get infected. I have lost contact with a lot of people because I could not meet them. I no longer go to the day care centre. I no longer go for respite. I miss my friends."

Brandy, 86

"Loss of control of where I could travel to visit my daughters living in in other counties, missed them and grandchildren so much, felt very isolated and lonely, had not been able to hug my mum, she lives near me, missed socialising with friends, made living alone harder. I've always enjoyed my own space, not so much now."

Nancy, 60

"It turned my life upside down! I missed my immediate and extended family. I am a very social person and involved in the community. I feel so sorry for my country..."

Timmy, 65

"I have lost my drive and have become more anxious. I struggle with decision making. I am spending much more time on my own. I am drinking more alcohol than usual. I have put on weight and do not feeling good about myself."

Peter, 61 
"Found it very difficult. I like to get out to shops and have a day out in Dublin, lunch etc. My children live abroad and received no support apart from a phone call once a week...... My husband is over 80 and relied totally on me for all supports..... I found it an extremely lonely time..."

\section{Georgiana, 68}

Others had similar negative experiences while still trying to remain upbeat:

"I have been in fair good health, since the start of the outbreak. The first few months of cocooning were fine but for the past while I find it lonely and depressing at times. No end in sight living alone the dark long winter nights coming. I am afraid to go out much as I had...there is not much I can do only try and keep safe and going."

$$
\text { Jean, } 85
$$

An overlooked aspect of feelings of loneliness is that they can be experienced in the company of others. One participant discussed how required isolation, although not alone, had impacted her mental health:

"I have been upset that I was asked to cocoon and afraid...I felt isolated and lonely even though I live with my daughter, son-in-law and granddaughter, upset I couldn't see my friends at bingo and wouldn't go to other children's house for a visit. Felt my general physical and mental health has declined from lack of mobility and exercise from being housebound and a lack of stimulation has affected my mental health and increased level of confusion at times."

Sandra, 84

Another participant highlighted that lockdown was particularly challenging for those older people who were single and had no significant other in their lives:

"It has been a difficult time for everyone young \& old... For us mature single people with no partners for whatever reason widowed, separated it's hard not getting out to meet up for a social drink, dance and just general company. There is nothing to look forward to or to break up the week. Some of the time we couldn't even have family visit. They say it's for our own safety so hopefully it will soon be over, and we can get back to some sort of a normal life please god."

Lorna, 60

\subsection{Frustration}

Social isolation also increased the sense of frustration with the events of the pandemic among a number of participants. For some, the recommendation to isolate and the time spent alone had a negative impact and led to feelings of being neglected or disregarded by decisionmakers and wider society. Some expressed annoyance at the feeling of being "forgotten", while there were also stronger statements, professing to "loathe" some of the representations of older people during the first period of lockdown. While these experiences are not exclusive to older people, there is cause for concern for the effect such negative feelings may have on mental health. These experiences can induce or exacerbate depressive symptoms and anxiety; they also tend to erode trust in public representatives and authorities. Such pressures are evident in many participants' responses:

"I found the lockdown very restricting and frustrating. I hated not being able to go to the shops and having to get my son to shop. I felt very lonely as did not see anyone apart from my son dropping the shopping."

Aoife, 75

"First thoughts, how can I stay self-isolated, cocooning, I had enough to occupy my time, catching up on things, reading some books, doing crosswords etc. Anything to keep my mind active. I felt lonely at times (my husband died May 2019) we had no family... I felt we were forgotten about at times by those in authority. I felt we had lost some of our dignity, having no say how we should live which was quite hurtful."

Sophie, 86

"My life has been restricted in every sense, simple pleasures such as visiting friends and family, retail therapy, midweek breaks, have all been curtailed. I have not attended mass since March doing the basic shopping has become something of a chore...

Sanitising wearing a mask keeping social distanced have all taken the enjoyment out of the experience. I particularly find masks most uncomfortable. I wear glasses which fog up regardless of all the remedies that I have used. I cannot make plans as we're being told that the virus is here for a long time and we've to learn to live with it."

Clara, 65 
One subject that emerged as a regular source of both frustration and anger was the use of the word "cocooning". Many participants commented that they found the public health advice surrounding the concept confusing, the restrictions personally unnecessary and the word itself disrespectful:

"I am extremely angry that I had to cocoon, although I am 80 I feel victimised as if a prisoner not allowed out. I suffer with numerous ailments like many others but feel ostracised. Although I have conditions, men a lot younger couldn't match my ability to accomplish tasks. The person who come up with the idea of cocooning should be made to experience it first-hand."

Willie, 80

"It annoys me that some members of the public don't think COVID precautions apply to them and these precautions/recommendations are not reinforced. I loathe the word 'cocooning."'

Philly, 76

"Being confined to my home was a bitter pill to swallow. It felt like being criminalised to leave my home and a bit too much altogether."

Eoin, 83

"Hated the word cocooning!"

Robert, 73

"I resent the singling out of the aged and older for 'cocooning'. It is not age as such which is relevant, but frailty, compromised or weak immune system and/or poor health. I may be slower than when I was younger, but I am not frail. I have a good immune system and am in reasonably good health."

Nora, 73

Expression of such frustrations is not lightly dismissed; it can undermine trust in and support for government and public health officials. This is particularly relevant considering the level of public support and trust required for adequate rates of vaccine uptake or for any future public restrictions and lockdowns thought necessary.

\subsection{Fear \& Anxiety}

In addition to frustration, fear and anxiety emerged as themes related to social isolation. Both found a range of expression in responses, but most prominently in a new, acute sense of uncertainty that accompanied the pandemic. Participants were commonly anxious and fearful regarding contracting COVID-19, and about the risks posed to the economy by enduring restrictions, and many expressed worry about the consequences for the country's youth. Isolation from family, friends and the larger community exacerbated such general anxieties and fears:

"COVID-19 has really scared me. I feel that life will not be the same again for a very long time, if ever. I fear that a number of people are not taking enough care in fighting this pandemic and that it will return again and again. At my age I feel very vulnerable and hope there will soon be a vaccine."

\section{Cathy, 78}

"COVID-19 has made me fearful in a way I never thought possible. I am in a constant state of anxiety which impacts on my mental and physical wellbeing."

Toni, 57

"Due to uncertain type of virus, very anxious time."

Christopher, 75

"Since COVID came to Ireland I feel stressed and unable to relax. I worry about family members and the effect on them. My work as a nurse in the community has made me more aware of older, unwell people isolated and worried, I am concerned for young people who are now out of work."

Patti, 63

"I am not really worried about COVID. I am more worried about the effect on the economy and the fear of a deep recession. Bleak future for the young people."

David, 75 
For some, feelings of fear and anxiety were compounded family members being abroad and at great physical distance:

"For the first two weeks, it's very difficult. I feel like it's the end of the world god knows. So anxious most of time thinking how my family back home in the [COUNTRY NAME REDACTED]."

$$
\text { Luis, } 60
$$

"It has caused me to feel anxious and worried about myself, husband and the family who live abroad. We missed visits from family and felt lonely at times."

Nicole, 69

One participant noted that feelings of worry and fear arose from the fact that their children were frontline workers who were potentially in contact with the virus every day:

"It was a very difficult period in my life. As a mother of adult children, three who were working on the frontline, it was very worrying. I worried for their health and safety, tried to provide as much support as possible to them \& listen to their stories, cried with their tears, prayed when one of them had to selfisolate because of close contact. They did not come home until June for a weekend it was so awful. I missed my grandchildren so much, their touch, the hugs and kisses. I felt depressed and despondent at times and afraid even when shopping. I missed having lunch or coffee with my friends. Texting, WhatsApp do not replace that human touch and interaction."

Freda, 59

Other participants who were in high-risk categories found isolation extremely worrying, but reported that support from friends and family made the experience more manageable:

"I was very frightened by it, it spread so quick, and as I had cancer 5 yrs ago I was told to be extra careful so I never left the house for 7 weeks, thankfully my daughter who lives close by did look after all my needs, shopping, medicine etc. I enjoyed the sun in the garden and very thankful to have one to the weather was fab. Still taking care."

Franny, 63
"I was diagnosed with COPD before the pandemic, so it was a time of great worry as I was very concerned around getting the virus. I am still very worried. I am quite an active person; I like going to my local town every day and socialising and going for coffee. I really missed this, and I realised how important it is for my mental health. I also realised how lucky I am I have a great family who looked out for me and made sure that I had all of the supplies that I needed."

Hillary, 69

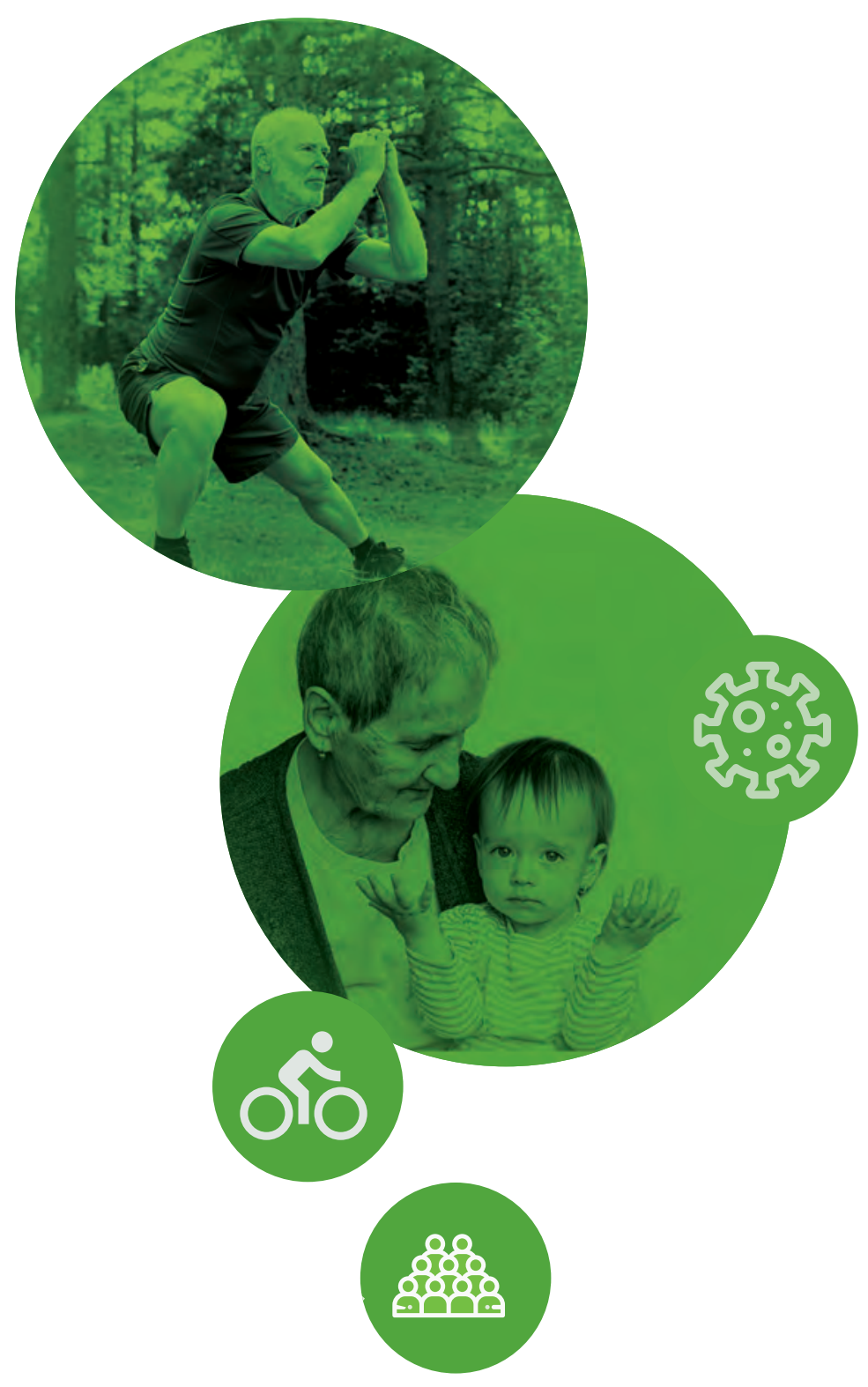




\section{Chapter 6 Hope \& Optimism}

\subsection{Introduction}

While there were many reasons for worry and for uncertainty about the future, TILDA participants were not lacking in hope for an eventual end to the pandemic or relative optimism about the future. This came through particularly in responses to the second open-ended question in the SCQ: "What is it that you are looking forward to do once COVID-19 ends?" Participants expressed optimism that the pandemic would have an end date, and that life would eventually return to normal. It was clear that most could quite clearly envision themselves in the future once again enjoying the company of their children, grandchildren, and other family and friends. Other participants could see themselves returning immediately to activities that had been put on hold due to COVID-19. Céilís and set dancing, five-a-side soccer, bridge tournaments, book groups, and coffee mornings were just some of the activities participants were keen to return to. Many expressed eagerness to continue with a new hobby or skill taken up during lockdown. These expressions of optimism speak again to a general level of emotional resilience among the over 60s in Ireland.

The three primary subthemes that emerged under the main theme of hope and optimism were: contact with family and friends; re-engagement with activities within the community; and hope for a more compassionate and just society once the pandemic ends.

\subsection{Contact with Family \& Friends}

The most immediate hope for many TILDA participants was a return to normality with family and friends. Participants regularly spoke of the understandable desire to be able to return to close and physical contact with family members and intimate friends. Being able to return to close contacts and visits in household settings was a common theme. Participants also looked forward to meeting one another without having to remain aware of standard pandemic requirements such as social distancing, face masks or hand washing:

"I'm looking forward to hugging my family, the old spontaneity of calling to friends and family without having to think of masks, gels and social distancing."

$$
\text { Jen, } 60
$$

"Looking forward to getting back to work and meeting friends and going for coffee and going shopping for clothes and doing all the normal things we took for granted. To enjoy life again and having no fear...to appreciate life and everything and everyone better."

Pat, 60

"Doing what I feel like doing. Going to mass on Sundays. Going to visit family \& relatives. Just doing what needs to be done and not have to think about health restrictions."

$$
\text { Reggie, } 86
$$

Participants in many cases were likewise hopeful for the return of the kinds of events cancelled or postponed due to the pandemic. Weddings, christenings, communions, anniversaries and birthdays all featured as missed events, and were eagerly anticipated once the most severe of restrictions were lifted:

"Celebrating the family occasions that have been postponed this year and getting back to social dancing and concerts. Being able to hug my family and friends again."

Fran, 62

"I'm hoping that my son in Australia will be able to come home for his postponed wedding \& that my little granddaughter can make her first holy communion and be a flower girl at her uncle's wedding."

Dee, 68

"Time with my wife \& family to celebrate our 50th wedding anniversary."

Kev, 73

Most participants also noted they're looking forward to a return to the normal routine with close friends:

"Meeting my friends (book club of 20 years) face to face. We've been Zooming but it's a pale limitation of easy conviviality. Getting dressed up, going out for a meal, feeling comfortable, physically in a space, or close up to a friend or stranger."

Niamh, 63 
"Meeting my friends and enjoying a game of bridge or poker or having a good meal together."

Josephine, 86

"Have a pint of Guinness with friends."

Tom, 76

\subsection{Reengagement with Activities}

The range and diversity of activities enjoyed by TILDA participants was notable, and another reason for a hope for an end to restrictions. These were in many cases, naturally, the hobbies and community activities that participants had been engaged with before the pandemic, but applied also to continuing new skills and hobbies taken up by participants during lockdown. Whether it be bridge, soccer, fishing, ballroom dancing, or playing a musical instrument, participants expressed great motivation and energy to return to or continue those activities that had provided them with structure and purpose before and during the course of the pandemic:

"I am looking forward to going to fishing competitions in all the lakes throughout the country next year."

Jamie, 66

"Ballroom dancing and general social activities and interactions with acquaintances."

Ian, 77

"Meeting friends and watching soccer in the local pubs. Foreign travel \& five a side soccer every week ..."

Alfred 65

"Going back to holidays abroad. Playing with amateur orchestra."

Kenny, 69

"Playing my banjo with a group of learners in a pub..."

Donald, 69
"Painting and yoga classes in person. Dressing up for a night out. Hugs and kisses. Our music session with 80 people which we had to cancel and do online definitely no fun."

Delia, 67

"Getting back to work full time \& getting back to fitness classes. Being more active \& having a full social life again. Can't wait!"

$$
\text { Maggie, 57s }
$$

One participant, who had used their time to record their experiences through the pandemic in a journal, was looking forward to submitting and publishing their work once lockdown had ended:

"I want to continue with my work of writing and having my work set up for printing and then having it published."

Jack, 83

Another participant was hoping to visit Lourdes and walk the Camino de Santiago through Spain once it was safe to do so:

"Visiting relatives in the UK. Booking a holiday, going to Lourdes and walking the Camino next year."

Jules, 67

\subsection{Social Hope}

Finally, a common theme in participants' contributions was the hope that this period would bring in its wake a permanent shift in attitudes toward a range of pressing social issues, including the national housing crisis, climate change, health, and social justice. These were all areas that participants hoped would benefit from new awareness and become the focus of more compassionate politics after the pandemic.

"I would hope that we might create a better, more just society, one that is seriously tackling climate change."

Debbie, 65 


\section{Chapter 7 Conclusion}

"What I'm really looking forward to is lessons to be learned by our politicians and to see what is really important in life and to implement the policies to end the health and housing crises."

Edith, 88

"Hoping that people will be more tolerant towards each other \& not be so materialistic."

Anna, 65

"We hope at this stage the numbers will decrease and we continue to follow the instructions of the professional advisors. We hope our country will act responsibly and the children will get back to enjoy school again. We would like to be able to plan ahead but hopefully we will remain calm, compassionate and help our communities to get back to normal. Best of luck and wishes for the future. Thank you."

\section{Bridget, 67}

Participants frequently voiced their support, appreciation and respect for all frontline workers during the pandemic, and they hoped that the greater levels of support and compassion for the most vulnerable in Irish society which they felt emerged during the pandemic would persist:

"A society that might continue to care for people as they did during COVID and a government that rewards and respects those frontline workers particularly nursing staff with actual financial improvements with pay and not the ongoing lip service and lack of respect."

Richie, 63

"Most of all to pay our hero health care workers a wage befitting to live in this country."

Eve, 66
To conclude, these findings make clear that there was not just one defining experience for older people during the initial months of the COVID 19 pandemic. There was in fact a variety of lived experiences and personal responses to the demands and challenges of the initial restrictions. Even under the dominant theme of normality there was diversity as some older people were affected by the absence of the public amenities and outlets that were no longer available, while others found the absence of their regular private relations with friends and family their primary struggle. Moreover, some participants discovered the real challenge was to their working lives due to either the suspension / loss of work or the heightened demands of work as front line workers, while others grappled with the disruption to regular religious experiences such as mass and funeral attendance or the receiving of holy communion.

Likewise, the methods by which people coped and demonstrated great resilience was also varied. Most respondents managed by maintaining a positive and grateful outlook, which kept their spirits uplifted throughout the first lockdown, while others adapted to the restrictions with patience and resolve. However, some participants looked upon the events of lockdown as an opportunity to cultivate a new hobby or skill, such as becoming more computer literate or learning a new language. Such openness to new opportunities proved to be a healthy outlet for manging the pressures of the pandemic.

A topic that did not seem to have such flexible solutions, however, was that of the experience of social isolation. For those in some of the most unfortunate of circumstances, the restrictions were accompanied by a reduction in social contact and heightened feelings of loneliness. Likewise, such instances of isolation also increased frustration at the circumstances of the pandemic, specifically with some of the public health messaging directed towards older people, which at times was interpreted as neglectful or too paternalistic. Additionally, for a small minority of respondents, isolation also increased the anxiety and worry for the future, as well as their concern regarding the long-lasting effects that the pandemic would have for their children and grandchildren. 
Despite the bleak initial circumstances of the pandemic, most participants were still eager to disclose their hope and optimism for the future once the emergency had stabilised. Such hope was expressed through regular anticipation of returning to the normal relations with friends and family. Likewise, the enthusiasm of returning and re-engaging with activities that had been suspended due to restrictions was a frequently expressed hope. Finally, optimism was expressed by many participants through a desire to see a fairer and more just society emerging from the solidarity cultivated through the most challenging periods of the pandemic.

A final, but pertinent point worth highlighting is the period under which these contributions were collected. TILDA participants returned their SCQ entries during the first initial wave of COVID 19 and social restrictions; principally the summer and early autumn months of 2020. The intermittent period between then and the publishing of this report has brought with it two successive waves and a prolonged winter period of additional restrictions. These subsequent societal lockdowns have undoubtably brought further challenges and hardships, potentially altering attitudes and perceptions among older people within Ireland. It is with this view in mind of the dynamic and rapidly changing nature of the pandemic that we plan to further collect the experiences of older people in future successive waves of data collection and analysis. In the interim period we have analysed and reported on many other components of the SCQ responses to assist with policy and practice. This is our final report from the data collection. Additionally, we will engage with other research agencies such as the Central Statistics Office and age-related NGOs to gain a more transparent and present account of the lived experience of older people throughout all stages of the pandemic.

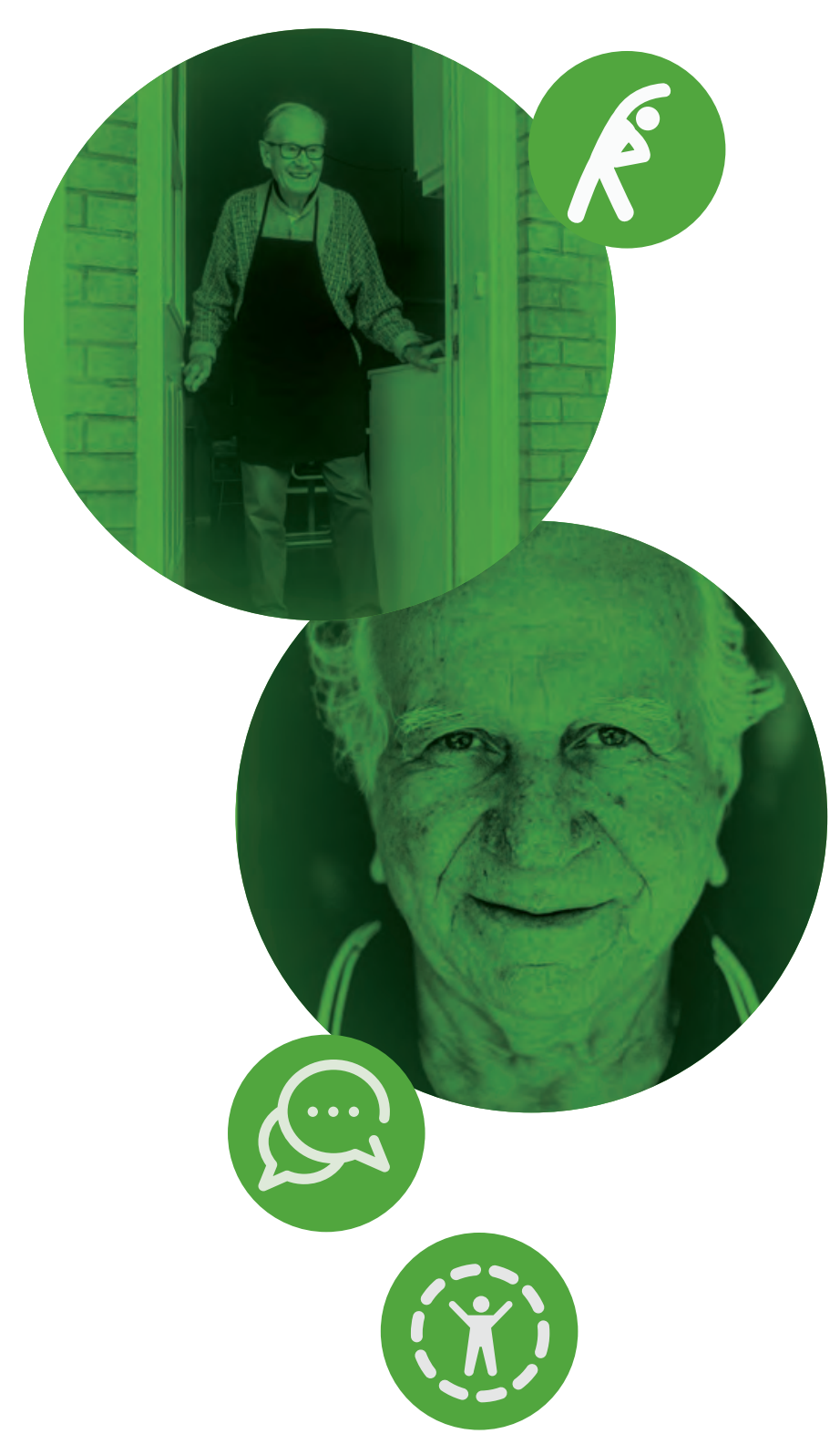




\section{Bibliography}

Age NI. (2020). Lived Experiences: Vocies of Older People on the COVID 19 Pandemic 2020. Belfast: Age NI.

Braun, V., \& Clarke, V. (2006). Using thematic Analysis in Psychology. Qualitative Research in Psychology, 3, 77-101.

Bryman, A. (2012). Social Research Methods (4th Edition ed.). London : Oxford University Press.

Chen, L. (2021). Older adults and COVID-19 pandemic: Resilience matters. Archives of Gerontology and Geriatrics, 1.

DEASP. (2020). The Intial Impacts of the COVID 19 Pandemic on Ireland's Labour Market: Working Paper. Dublin: Department of Employment Affairs and Social Protection.

HSE. (2021). COVID 19 Pandemic Impact Paper. Dublin: Health Service Executive.

HSE. (2021). Weekly Report in the Epidemiology of COVIF 19 in Ireland. Dublin: Health Service Executive.

Ioannidis, J., Axfors, C., \& Contopoulos-loannidis, D. (2021). Second versus first wave of COVID-19 deaths: Shifts in age distribution and in nursing home fatalities. Enviornmental Research, 195, 1-7.

doi: https://doi.org/10.1016/j.envres.2021.110856

Jackowska, M., Brown, J., Ronaldson, A., \& Spetoe, A. (2016). The impact of a brief gratitude intervention on subjective well being, biology and sleep. Journal of Health Psychology, 21(10), 2207-2217. doi:

https://DOI: 10.1177/1359105315572455

Killen, A., \& Macaskill, A. (2015). Using a Gratitude Intervention to Enhance Well-Being in Older Adults. Journal of Happiness Studies, 16, 947-964. doi: https://DOI 10.1007/s10902-014-9542-3

Rash, J., Matsuba, M., \& Prkachin, K. (2011). Gratitude and Well-Being: Who Benefits the Mostfrom a Gratitude Intervention?aph. Applied Psychology: Health \& Wellbeing, 3(3), 350-369. doi: https://doi:10.1111/j.1758-0854.2011.01058.x

Ward, M., Clarke, N., \& Wang, M. e. (2021). Study protocol for TILDA COVID-19 survey. Altered lives in a time of crisis: Preparing for recovery from the impact of the COVID-19 pandemic on the lives of older adults. HRB Open Resource.

Ward, M., O'Mahoney, P., \& Kenny, R. (. (2021). Altered lives in a time of crisis: The impact of the COVID-19 pandemic on the lives of older adults in Ireland Findings from the Irish Longitudinal Study on Ageing. Dublin: TILDA. doi:

https://DOI:10.38018/TildaRe.2021-01

Wells, M. (2010). Resilience in older adults living in rural, suburban, and urban areas. Online Journal of Rural Nursing and Healthcare, 10(2), 45-54.

Windle, G., Woods, R., \& Markland, D. A. (2010). Living with Ill-Health in Older Age: The Role of a Resilient Personality. Journal of Happiness Studies, 11, 763-777.

\section{Appendix:}

\section{Other Resources}

Since the start of the COVID-19 pandemic in March 2020, TILDA has produced numerous research publications to inform the public health response to the pandemic. These, along with previously published TILDA reports, can be accessed here: https://tilda.tcd.ie/ publications/reports/, here: https://tilda.tcd.ie/CovidData/reports/ and here:

https://tilda.tcd. ie/CovidData/briefs/ 
